\title{
TECHNOLOGICAL BASING OF USING PHYTOTECHNOLOGIES IN CLEANING SEWAGE OF SMALL COMMUNITIES
}

\author{
Mykyta Riabchynskyi \\ Kharkiv National Municipal Academy, Kharkiv, Ukraine
}

\section{INTRODUCTION}

Currently $70 \%$ of polluted sewage is coming from minor sources, located in the countryside. This is because the overwhelming majority of small settlements don't have any facilities for cleaning sewage, and existing facilities work unsatisfactorily because of the wrong maintenance and absence of funds for repair.

In many countries during the last decades little villages got rid of traditional ways of cleaning sewage because of unreliability and difficulty in exploitation of cleaning facilities of standard type. Instead of those, widely used are facilities, which are based on intensification of natural process of self-cleaning of water, using microorganisms and highest aquatic vegetation. These methods of cleaning sewage using vegetation components are called phytotechnology. The most widely spread facilities using phytotechnology are bio-ponds and bio-plateaus. In this project I examine bio-plateaus in detail.

Bio-plateau is an earth structure (rarely ferroconcrete), which is made in half-hollow halfembankment

Cleaning structures based on phytotechnology are divided into

-structures of mechanical cleaning (precipitation tank)

-seepage blocks with vertical and horizontal movement of water

-shallow blocks

-floating Bioplato

-channel Bioplato

-coast Bioplato 


\section{CONSTRUCTION SPECIFICATIONS}

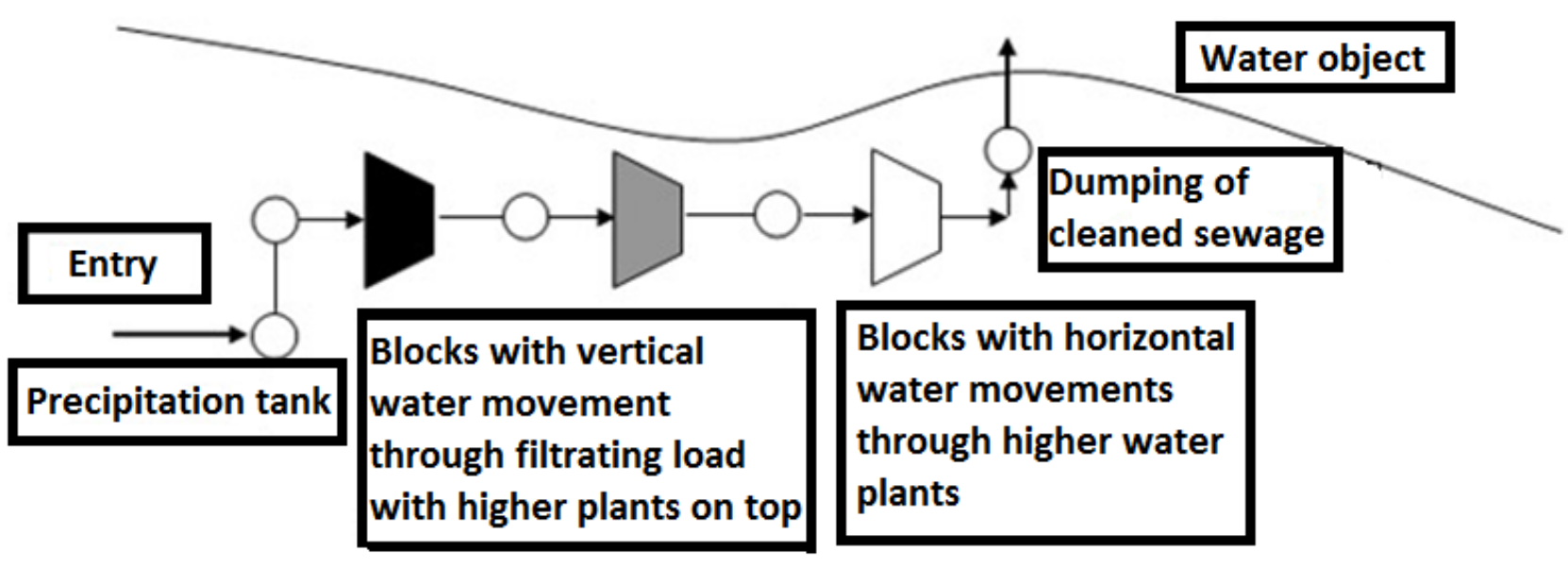

Figure 1. Plan of complex cleaning of sewage using phytotechnology "Bioplato".

Infiltration Bioplato is a ground filtration structure filled with crushed stone, gravel, haydite, sand or other discret filtrating materials.

There are two types of infiltration Bioplato:

-with horizontal filtration

-with vertical filtration

There are trees, bushes or grass planted on the surface of the structures. Cleaning of sewage takes place because of the symbiotic activity of vascular plants, biofilm, microphytes, microorganism, mushrooms and ray fungus in the rizosphere of the plant system rootage.

In horizontal filtration blocks, water is cleaned when it passes through thick filtration layer under the impact of microorganisms and plants root zone.

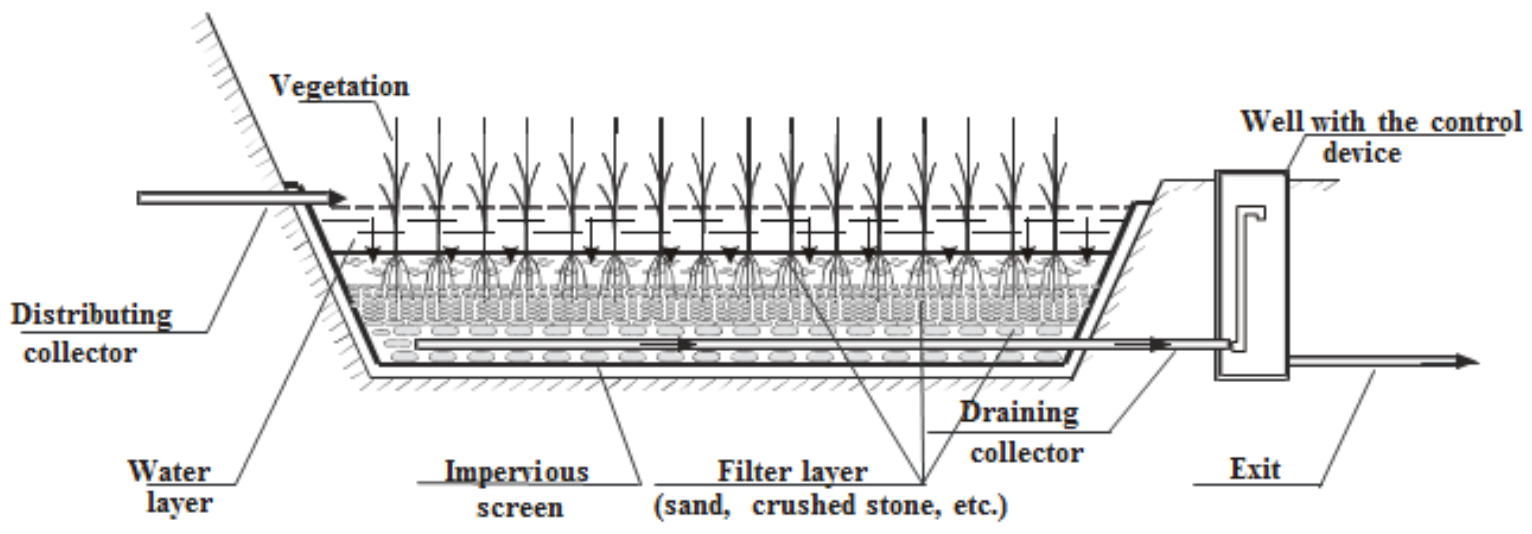

Figure 2. Scheme of filtrating Bioplato with vertical filtration. 
In vertical filtration blocks water, as it gets on the block (section), is firstly distributed along its surface in horizontal direction and at the same time because of gravitational force moves down, passes through the root system and filters and exits through scruppers into the well. Water is cleaned in the following stages:

-in open water zone

- in the plants root zone

- in the filter zone

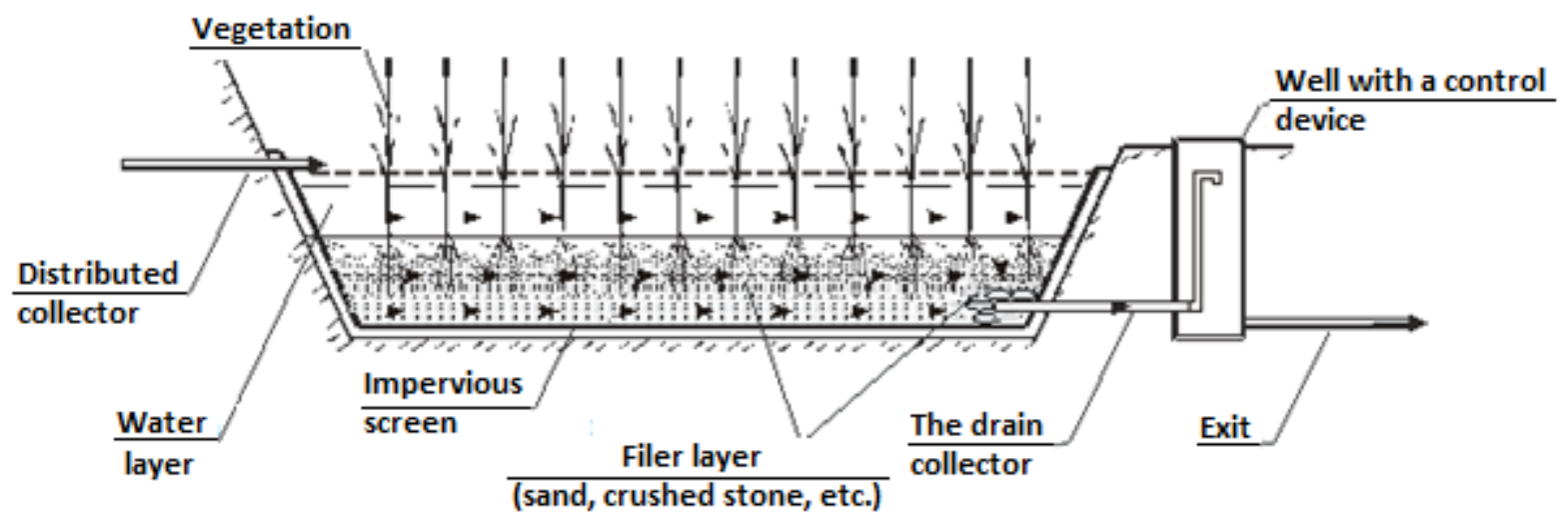

Figure 3. Scheme of filtrating Bioplato with horizontal filtration.

Filtrating Bioplatos, which don't have any open surface are called subsurface filtrating Bioplatos and are used if a distance to the residential sector is less than the size of the sanitary zone.

In these structures the filtrating layer is covered on top by ground plant layer, which consists of water plants. So the peculiar domestic sewage smell doesn't exist. Cleaning happens only in rizosphere of plants root system and filtrating layer because of activity of group of vascular plants and biofilm, microphytes, microorganism, mushrooms and ray fungus.

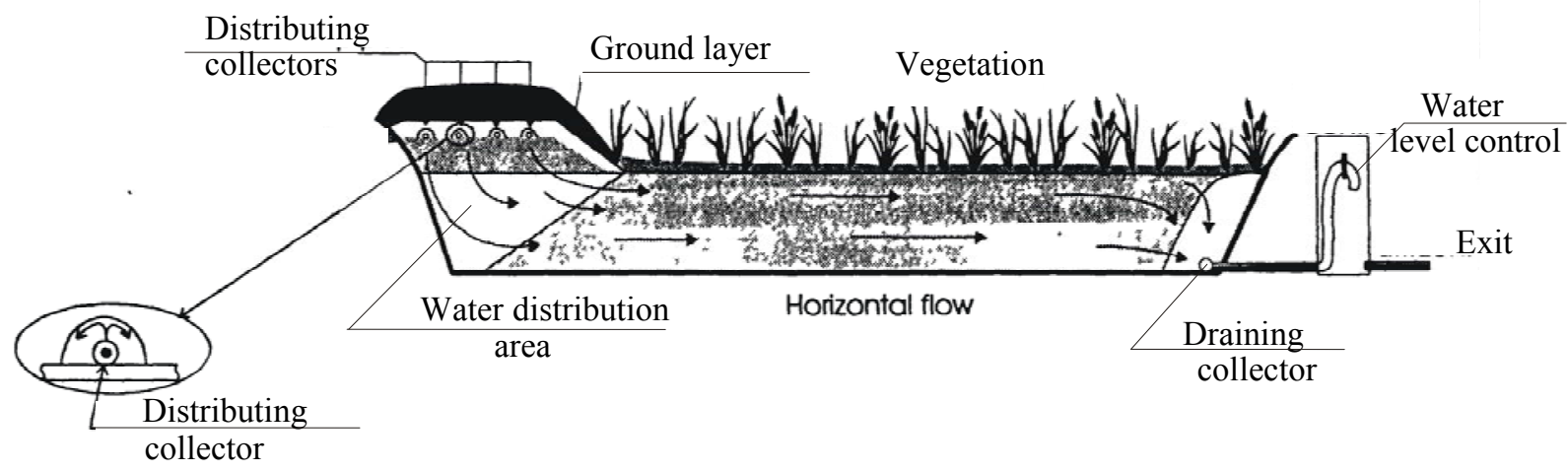

Figure 4. Scheme of subsurface filtrating BIOPLATO. 
Surface Bioplato. After cleaning through the infiltration blocks, sewage is further cleaned at the surface block of Bioplato with horizontal water movement through the root zone and the overground part of artificially made group of higher water plants. Bottom and sides of artificially made blocks are isolated by protective anti-filtering shield of the same type as in the infiltration Bioplato.

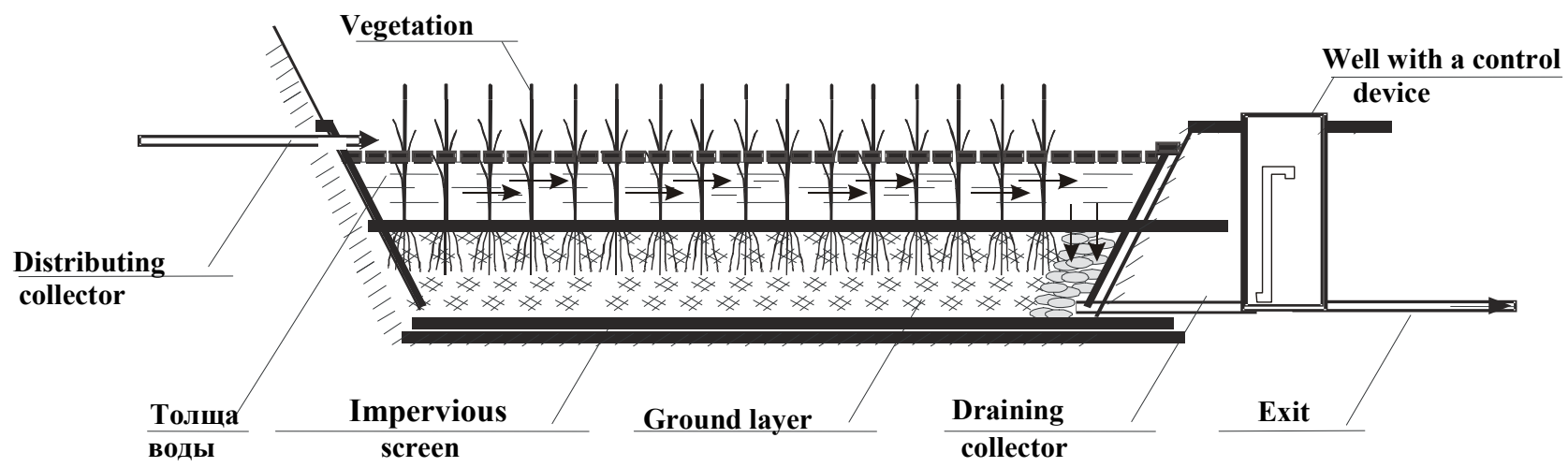

Figure 5. Scheme of surface Bioplato.

Bioplato with floating constructions is a system of tanks filled with water, at the surface there are nets of synthetic fibers, stems and leaves of water plants. There are plants with developed root systems planted into cells.

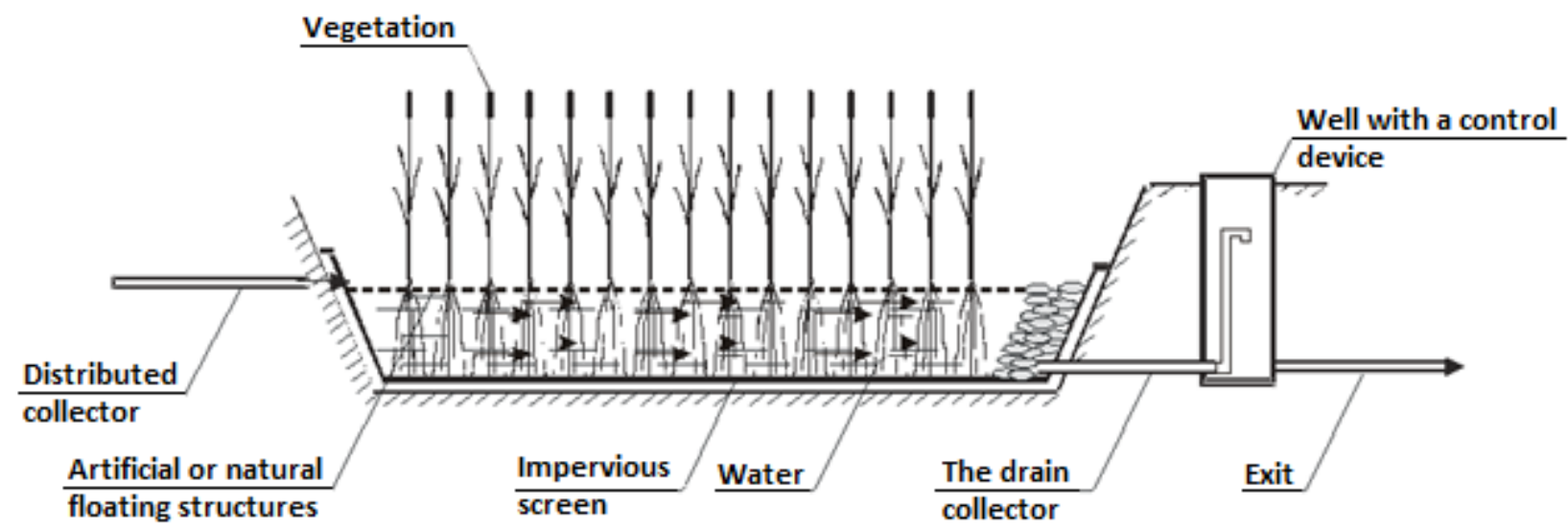

Figure 6. Scheme of bioplato with floating constructions

Bioplato with freely-floating plants is a system of water-filled tanks and plants (water hyacinth) or seaweed floating on the surface. 


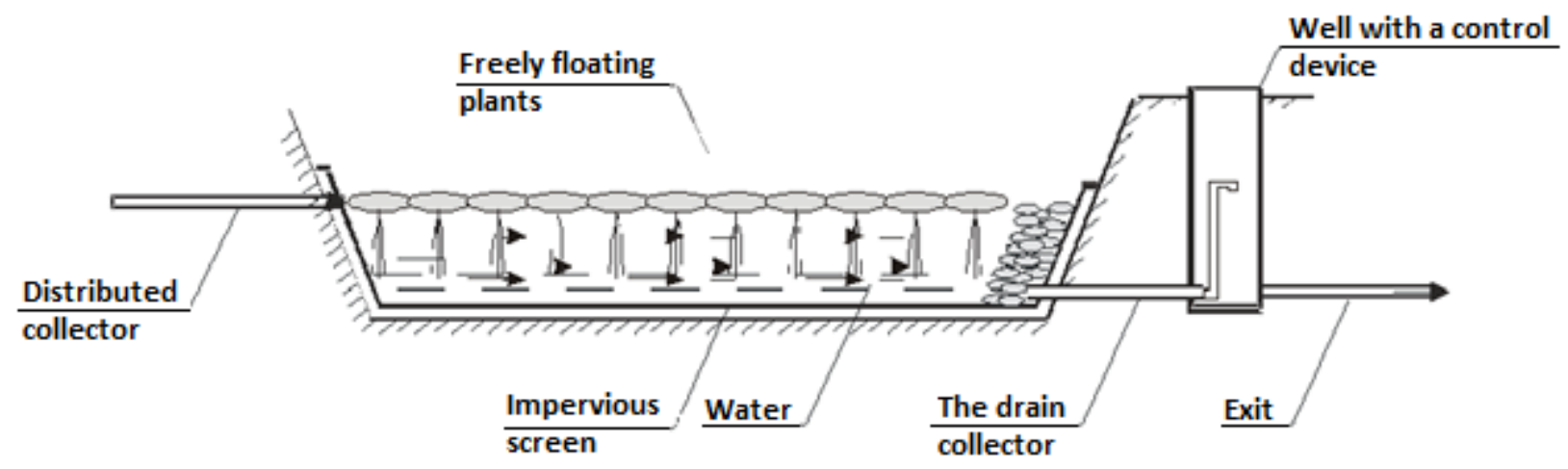

Figure 7 Scheme of bioplato with freely-floating plants

Constructions of these types proved themselves well in cleaning water from floating admixtures (foam, flakes, mineral oils)

\section{TREATMENT CHARACTERISTICS}

Main indicators of treatment are given below:

- By BOD 90-95\% (under 5-6 mg/l)

- By COD 85-95\%

- By suspended matters 95-99\% (under 4-5 mg/l)

- By mineral oils under 0-0.05 mg/l

- SSAS (surface active substances) over $85 \%$

- By mineralization 20-99\%

- Cleaned water transparency reaches $30 \mathrm{~cm}$ by Snellen

- By bacteriological index 98-99\%

- Smell is completely eliminated

- Amount of dissolved oxygen is increased

- Amount of nitrogen and phosphorus compounds is decreased by $35-60 \%$

The following graphs show the measurements of main pollutants taken on a number of Bioplatolike structures during the cold and warm seasons. 
Table 1. Measurements of main pollutants taken on a number of Bioplato-like structures during the cold and warm seasons

\begin{tabular}{|c|c|c|c|c|c|c|}
\hline \multirow[b]{2}{*}{ Indicators } & \multicolumn{5}{|c|}{ Sampling points } & \multirow{2}{*}{$\begin{array}{c}\text { The overall } \\
\text { efficiency of the } \\
\text { bioplato, } \%\end{array}$} \\
\hline & $\begin{array}{c}1 \\
\text { (enter) }\end{array}$ & $\begin{array}{c}2 \\
\text { (enter to } \\
1 \text {-st } \\
\text { block) }\end{array}$ & \begin{tabular}{|c|}
3 \\
(exit from \\
1-st block)
\end{tabular} & $\begin{array}{c}4 \\
\text { (exit } \\
\text { from 2- } \\
\text { nd } \\
\text { block) }\end{array}$ & $\begin{array}{c}5 \\
\text { (exit from } \\
\text { 3-rd block) }\end{array}$ & \\
\hline \multicolumn{7}{|c|}{ Transparency, cm } \\
\hline The average -summer & 0,43 & & 5,94 & 15,42 & 27,07 & \\
\hline Average - Winter & 4,06 & & 6,97 & 18,53 & 26,91 & \\
\hline $\begin{array}{l}\text { The average for the } \\
\text { period of observation }\end{array}$ & 2,25 & & 6,46 & 16,97 & 26,99 & \\
\hline \multicolumn{7}{|c|}{ The smell, the score } \\
\hline The average -summer & 4,00 & & 3,50 & 2,00 & 0,30 & \\
\hline Average - Winter & 3,00 & & 3,10 & 1,20 & 0,20 & \\
\hline $\begin{array}{l}\text { The average for the } \\
\text { period of observation }\end{array}$ & 3,50 & & 3,30 & 1,60 & 0,25 & \\
\hline \multicolumn{7}{|c|}{ Suspended solids, $\mathrm{mg} / \mathrm{dm}^{3}$} \\
\hline
\end{tabular}


Linnaeus ECO-TECH 2012

Kalmar, Sweden, November 26-28, 2012

\begin{tabular}{|c|c|c|c|c|c|c|}
\hline $\begin{array}{l}\text { The average for the } \\
\text { period of observation }\end{array}$ & 284,99 & 212,75 & 80,72 & 25,02 & 13,58 & $95,23 \%$ \\
\hline \multicolumn{7}{|c|}{ Dissolved oxygen, $\mathrm{mg} / \mathrm{dm}^{3}$} \\
\hline The average -summer & 1,77 & & 0,59 & 1,16 & 4,77 & \\
\hline Average - Winter & 2,82 & & 0,08 & 0,95 & 8,89 & \\
\hline $\begin{array}{l}\text { The average for the } \\
\text { period of observation }\end{array}$ & 2,29 & & 0,33 & 1,06 & 6,83 & \\
\hline \multicolumn{7}{|c|}{$\mathrm{COD} \mathrm{mgO} / \mathrm{dm}^{3}$} \\
\hline The average -summer & 241,84 & & 48,01 & 34,61 & 27,58 & $88,60 \%$ \\
\hline Average - Winter & 135,29 & & 79,99 & 21,83 & 19,96 & $85,25 \%$ \\
\hline $\begin{array}{l}\text { The average for the } \\
\text { period of observation }\end{array}$ & 188,57 & & 64,00 & 28,22 & 23,77 & $87,40 \%$ \\
\hline \multicolumn{7}{|c|}{ BOD $\mathrm{mgO}_{2} / \mathrm{dm}^{3}$} \\
\hline The average -summer & 116,84 & & 24,49 & 11,95 & 5,11 & $95,62 \%$ \\
\hline Average - Winter & 38,52 & & 26,88 & 5,72 & 2,47 & $93,59 \%$ \\
\hline $\begin{array}{l}\text { The average for the } \\
\text { period of observation }\end{array}$ & 77,68 & & 25,69 & 8,83 & 3,79 & $95,12 \%$ \\
\hline
\end{tabular}


Permanganate oxidation $\mathrm{mgO}_{2} / \mathrm{dm}^{3}$

\begin{tabular}{|c|c|c|c|c|c|c|}
\hline The average -summer & 36,04 & & 12,93 & 7,88 & 7,60 & $78,91 \%$ \\
\hline Average - Winter & 25,32 & & 21,05 & 5,49 & 4,74 & $81,29 \%$ \\
\hline $\begin{array}{c}\text { The average for the } \\
\text { period of observation }\end{array}$ & 30,68 & 16,99 & 6,68 & 6,17 & $79,89 \%$ \\
\hline
\end{tabular}

Ammonia nitrogen, mg/ $\mathrm{dm}^{3}$

\begin{tabular}{|c|c|c|c|c|c|c|}
\hline The average -summer & 59,29 & & 52,84 & 43,06 & 30,27 & $48,95 \%$ \\
\hline Average - Winter & 50,43 & & 87,09 & 37,16 & 23,51 & $53,37 \%$ \\
\hline $\begin{array}{c}\text { The average for the } \\
\text { period of observation }\end{array}$ & 54,86 & 69,97 & 40,11 & 26,89 & $50,99 \%$ \\
\hline
\end{tabular}

Orthophosphate, $\mathrm{mg} / \mathrm{dm}^{3}$

\begin{tabular}{|c|c|c|c|c|c|c|}
\hline The average -summer & 0,84 & & 0,40 & 0,33 & 0,37 & $55,56 \%$ \\
\hline Average - Winter & 0,26 & & 0,22 & 0,15 & 0,12 & $54,19 \%$ \\
\hline $\begin{array}{c}\text { The average for the } \\
\text { period of observation }\end{array}$ & 0,55 & 0,31 & 0,24 & 0,25 & $55,24 \%$ \\
\hline
\end{tabular}

Total phosphorus, $\mathrm{mg} / \mathrm{dm}^{3}$ 
Linnaeus ECO-TECH 2012

Kalmar, Sweden, November 26-28, 2012

\begin{tabular}{|c|c|c|c|c|c|}
\hline The average -summer & 5,96 & 7,058 & 7,10 & 5,32 & $10,73 \%$ \\
\hline Average - Winter & 6,70 & 6,07 & 7,95 & 5,10 & $23,88 \%$ \\
\hline $\begin{array}{l}\text { The average for the } \\
\text { period of observation }\end{array}$ & 6,33 & 6,56 & 7,53 & 5,21 & $17,69 \%$ \\
\hline \multicolumn{6}{|c|}{$\mathrm{SSAS}, \mathrm{mg} / \mathrm{dm}^{3}$} \\
\hline The average -summer & 0,281 & 0,125 & 0,056 & 0,018 & $93,46 \%$ \\
\hline Average - Winter & 0,393 & 0,272 & 0,114 & 0,068 & $82,70 \%$ \\
\hline $\begin{array}{l}\text { The average for the } \\
\text { period of observation }\end{array}$ & 0,337 & 0,198 & 0,085 & 0,043 & $87,19 \%$ \\
\hline \multicolumn{6}{|c|}{ Chlorides, $\mathrm{mg} / \mathrm{dm}^{3}$} \\
\hline $\begin{array}{l}\text { The average for the } \\
\text { period of observation }\end{array}$ & 44,21 & 49,72 & 51,33 & 42,43 & $4,04 \%$ \\
\hline \multicolumn{6}{|c|}{ Sulfates, $\mathrm{mg} / \mathrm{dm}^{3}$} \\
\hline $\begin{array}{l}\text { The average for the } \\
\text { period of observation }\end{array}$ & 262,57 & 329,95 & 239,04 & 244,84 & $6,75 \%$ \\
\hline \multicolumn{6}{|c|}{ The dry residue, $\mathrm{mg} / \mathrm{dm}^{3}$} \\
\hline $\begin{array}{l}\text { The average for the } \\
\text { period of observation }\end{array}$ & 870,33 & 1175,4 & 969,38 & 974,08 & $-11,92 \%$ \\
\hline
\end{tabular}




\begin{tabular}{|c|c|c|c|c|c|}
\hline \multicolumn{6}{|c|}{ Bacterial contamination, (coli - forms, the index $\times 10^{5}$ ) } \\
\hline The average -summer & 11257 & 309,24 & 102,06 & 22,62 & $99,80 \%$ \\
\hline Average - Winter & 4775,6 & 1206,3 & 503,41 & 4,03 & $99,92 \%$ \\
\hline $\begin{array}{l}\text { The average for the } \\
\text { period of observation }\end{array}$ & 8016,4 & 757,79 & 302,73 & 13,32 & $99,83 \%$ \\
\hline \multicolumn{6}{|c|}{ Bacterial contamination, (coli-phages (PFU x1000)) } \\
\hline The average -summer & 2615,7 & 36,47 & 9,25 & 6,40 & $99,76 \%$ \\
\hline Average - Winter & 526,43 & 109,86 & 9,14 & 3,86 & $99,27 \%$ \\
\hline $\begin{array}{l}\text { The average for the } \\
\text { period of observation }\end{array}$ & 1571,1 & 73,16 & 9,20 & 5,13 & $99,67 \%$ \\
\hline
\end{tabular}

- Cleaning of suspended materials is of higher quality during winter period because of decrease in water speed and increase in process of sedimentation

- Amount of dissolved oxygen increases in winter period because most of the water surface is covered by ice

- Amount of BOD and COD depends solely on the number of organic pollutants in different periods

- Improvement in water purification from bacteria depends on the water temperature. If the water temperature is too low, the bacteria and viruses die 

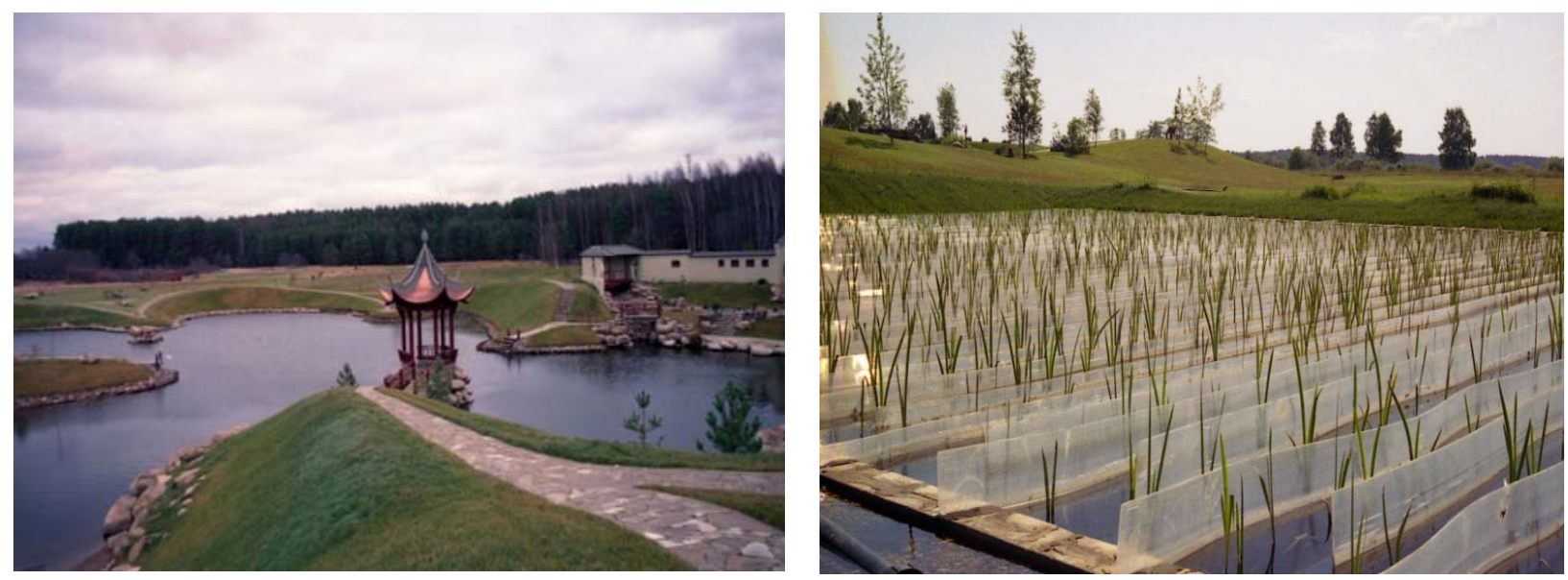

Figure 8. Working constructions.

As you can see on the slide blocks of Bioplato structure have a big advantage in aesthetic and can be used as leisure zones or decorating reservoirs. The major part of costs for building this type of structures is the cost of area, used for building.

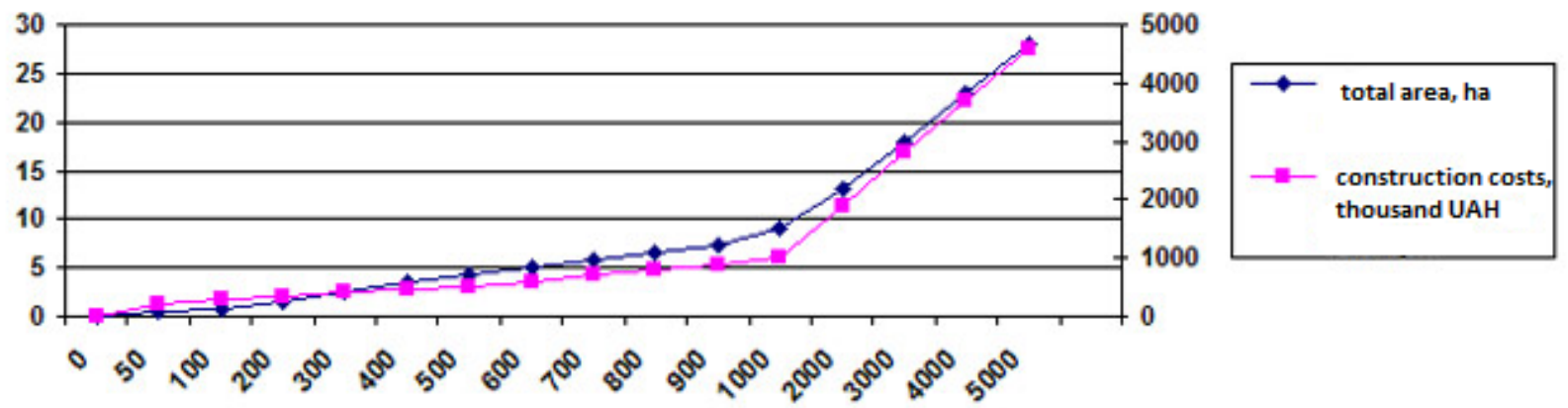

Figure 9. Graph of cost of bioplato compared to its building area.

Compared with the traditional sewage-cleaning structures, the Bioplato has some major advantages. Since nearly all works are connected with soil and large-scale reinforced concrete and iron elements are not used, electricity is not needed, the main long-term components are polyethylene pipes and screens and local materials, the capital expenses are far lower. 


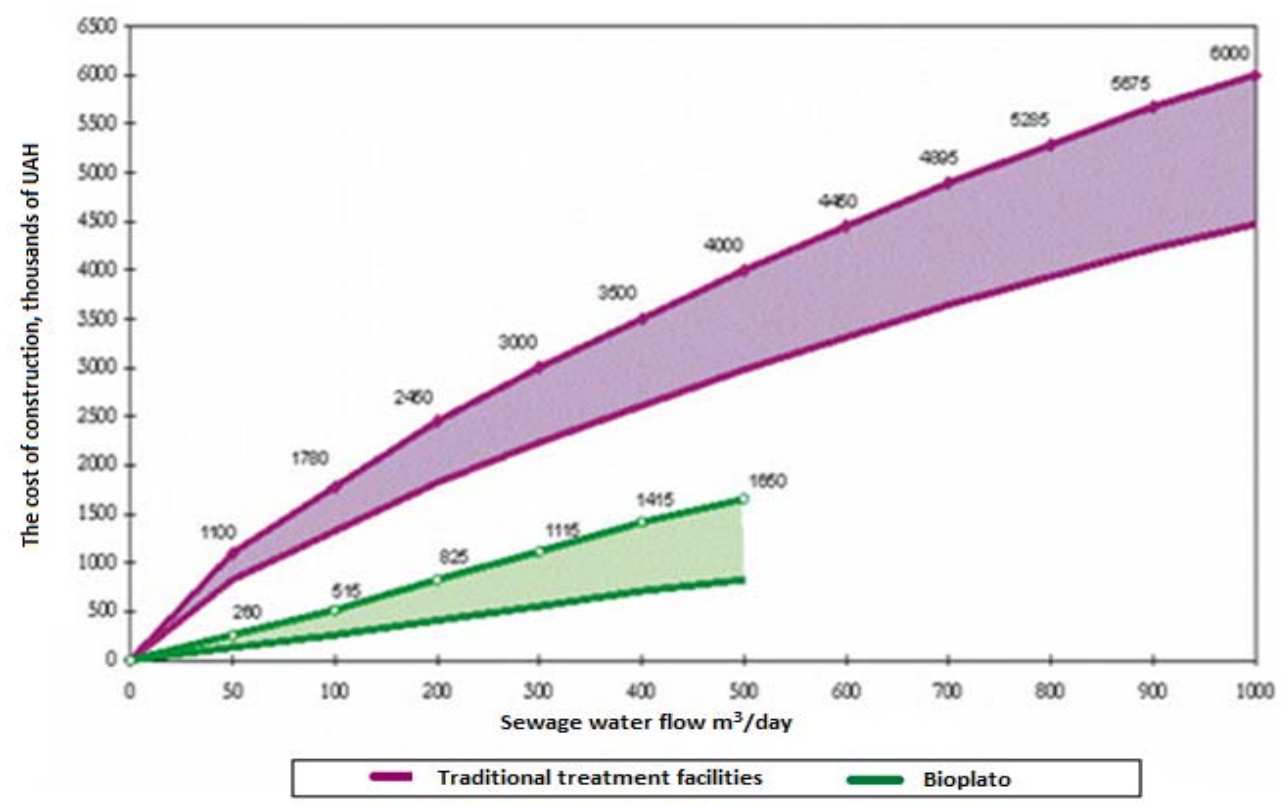

Figure 10. Comparison of capital investment into the cleaning structures.

Absence of reagents, electricity, jobbing once in 5 years, major repairs once in 40-50 years, selfregulating system.

As for the daily maintenance, it is lower due to the fact that we do not need electricity, chemical agents and regular technical maintenance and big salaries for a number of employees. The repair periods are 5-10 years and consist of only mixing og the top layer of filtering materils and replanting.

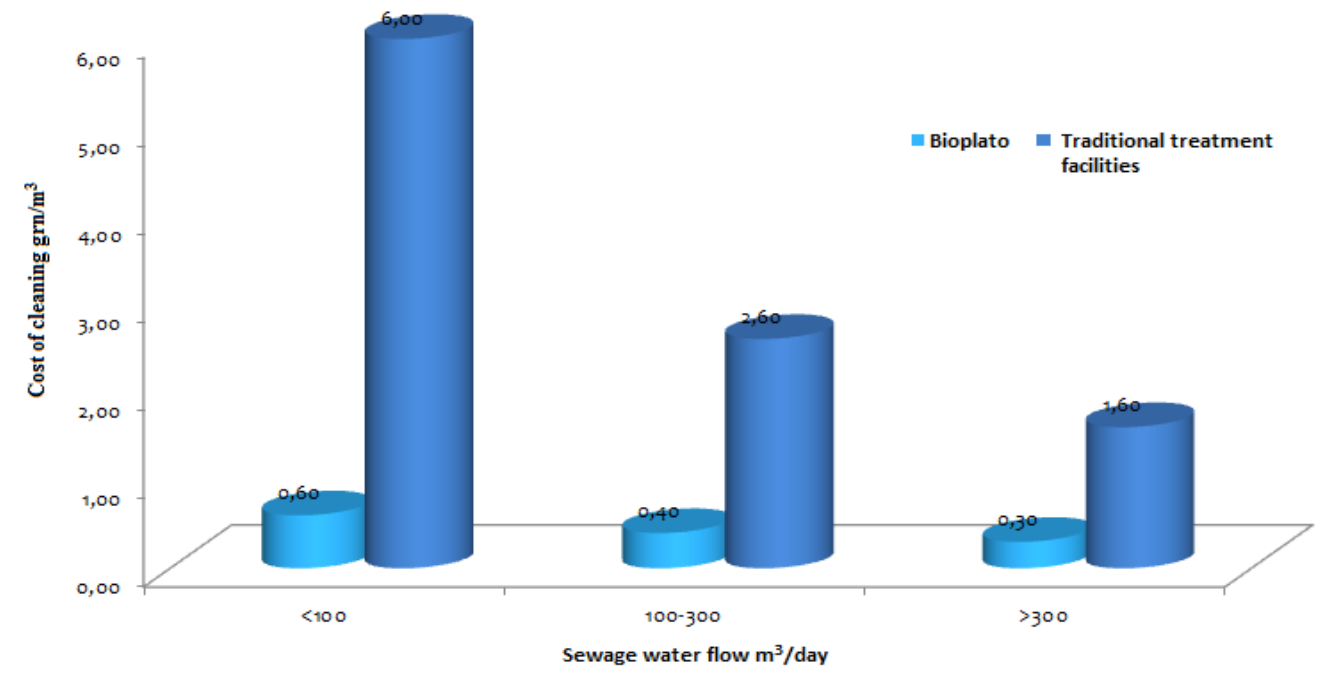

Figure 8. Cost per unit for exploiting of cleaning structures 


\section{CONCLUSION}

The table (Appendix A) shows total expenses, which are clearly indicate the Bioplato's advantages due to the above-mentioned reasons and also big role play the long periods between maintenance, which are 30-50 years for the CIS countries and 50-75 years for Western Europe and the USA.

- The report proves that construction based on phytotechnology of BIOPLATO type is an optimal choice for cleaning sewage in cottage settlements, small towns and camps.

- The analysis of literature sources gives economic and technological basis of using BIOPLATO complex along with traditional cleaning structures or as stand-alone structures.

- It is absolutely obvious that BIOPLATO, compared to classical cleaning structures, has an esthetic advantage. It can be built with local materials and plants, so it will not stand out against the surrounding nature's complex.

- Phytotechnology structures are also notable for proliferation of the natural self-cleaning principle, which makes the structure safer for the environment and saves workers from contacting hazardous chemical agents and other dangerous substances.

\section{ACKNOWLEDGEMENTS}

I want to thank to my university supervisor Professor Stanislaw Dushkin who was an excellent teacher and to Prof. Felix Stolberg for his invaluable assistance in the preparation of the master's work that was a base for making this article.

\section{REFERENCES}

[1] Jia Hongyu, Sun Tieheng, Li Peijun, et. al. New advances in the land treatment technology for wastewater. // Techniques and equipment for environmental pollution control. 2001. - V. 2, №1 - P. $62-65$.

[2] V. Yakovlev, the Ravens JV Collection and treatment of wastewater. Moscow: DIA. 2002. - $704 \mathrm{p}$.

[3] Stolberg FV Ladyzhenskii VN Urban ecology. - K.: Libra, 2000. - 464.

[4] Sun Tieheng Wastewater Eco-treatment Technological System and Its Developing Trends. / / Research of Soil and Water Conservation. - 2004. V. 11, № 3. - P. 1 - 3.

[5] Sun Tieheng, Zhou Qixing, Li Peijun. Pollution Ecology. BeiJing: Science. 2001 - 760 p.

[6] Seidel K. Abbsu von bacterium coli wasselpnanzen / / Naturwiss. - 1964. - V. 51. RM 395,404 .

[7] Seidel K. Reingung von Gewassern dutch hohrre pflanze / / Naturwiss. - 1964. V. 53. P. $289-297$.

[8] Feng Peiyong, Chen Zhaoping Jing Yuanxiao Review on constructed wetland and iits mechanisms of wastewater treatment / / Ecological Science. - 2002. V.21, № 2. - P. 264 268.

[9] Stolberg FV Ladyzhenskii VN, A. Spirin Bioplato - efficient low-cost environmental technology of sewage treatment / / Ekologiya dovkiilya that BEZPEKA zhittyadiyatelnosti. - 2003. Number 3. - P. 32

[10] Water Pollution Control Federation (WPCF), Manual of practice: natural systems for 
wastewater treatment. Manual of Practice FD-16, Chapter 13: Wetland Systems. Alexandria: VA., 1990. - 164 p.

[11] Gunther G., Gunhild H.. Qualitatsmanagement im Ingeniurwesen am Bispiel "Bewachsene Bodenfilter" / / Wasser und Boden. - 2003. V. 55, N. 3. - RM 1115.

[12] Sun Tieheng, Zhou Siyi technical regulations of municipal wastewater using the fields land. Beijing: Chinese environmental science, 1997. - $230 \mathrm{p}$.

[13] Lei Zhihong, et.al. High Efficiency Composite Artificial Wetland System with Vertical Flow for Wastewater Treatment and Reuse / / Water \& wastewater engineering - 2002. V.38, № .9. - RM 2224.

[14] Jia Hongyu, et. al. One of the plants natural bioremediation of waste water. Chinese patent, № application 03238079.82003

[15] Chen Xiaodong, Chang Wenyue, Jia Hongyu, et. al. One of the technologies of waste water purification, combined natural and artificial biological cleaning. Chinese patent, № application 03133907.72003

[16] Lin Zhiqing Selenium removal by constructed wetlands: Quantitative importance of biological volatilization in the treatment of selenium laden agricultural drainage water // Terry Norman. Environ. Sci. and Technol. - 2003. V 37, №3. - P. $606-615$.

[17] Rivera R. et. al. The application of the root zone method for the treatment and reuse of high-strength abattoir waste in Mexico // Water Science and technology. 1997. - V. 35, № 5. - P. 271278

[18] Knight R. L. et.al. Constructed wetlands for lifestock wastewater management. // Ecological Engineering. - 2000. V 15. - P. $41-55$.

[19] Walker D. J., et.al., The reduction of heavy metals in a storm water wetland. // Ecological Engineering. - 2002 V. 18, № 4. - P. $407-414$.

[20] Kigel EM Operation of sewage treatment facilities. - Kiev: Builder, 1978. -143 Sec.

[21] Titov, YP, Yakovenko, NM Pumping stations Water Supply and Sanitation. - Kharkov: HGAGH, 2001. - 176 p.

[22] Dushkin, SS, Kulikov NI, Drozd GY Operation of drainage networks. - Kharkov, 1999. $-229 \mathrm{p}$.

[23] Wedges IJ The corrosion of chemical equipment and corrosion-resistant materials: Textbook for Universities. Publishing revised and updated - Mashgiz. - Moscow, 1960. $511 \mathrm{p}$.

[24] Kalitsun VI, Cedars VS Laskov JM Safonov, PV Hydraulics, water supply and sewerage: Textbook for Universities. Izdatelstvo3's, revised and updated. - Moscow: Stroizdat, 1980. - $356 \mathrm{p}$.

[25] Bardakov VA Methodological guidelines for the economic part of the graduation project. - Kharkov: HGAGH, 2003. - 67.

[26] Zhiglo Y. Methodological guidelines for occupational health section in the graduation project. - Kharkov, 2003. - 30.

[27] VD Rudenko, Makarchuk AM, Patlanzhoglu MA Computer Course: A Tutorial. -Kiev. In 1998. - 367s

[28] Fedorov, NF, Shifrin S. Sewage: A manual for schools. - Moscow High School. In 1968. - $591 \mathrm{p}$.

[29] SV Yakovlev, YM Laskov Drain. Publisher 6th redesigned and enlarged - Moscow, Stroizdat. In 1978. - 221 p. 
[30] Oxalis O. Prospect of bioplato UTSF. - Kharkov. In 2003. - 10. A. Sergeev Safety instructions for operation of sewerage facilities. - Moscow, Transport. In 1971. - $135 \mathrm{p}$.

[31] SNiP 2.04.03-85 Drain. External networks and sooruzheniya.Goskom USSR for construction. Moscow. 1986.-72. 